\title{
INVESTIGATIONS OF DIESEL ENGINE IN THE ROAD TEST
}

\author{
Oleksandr GRYTSYUK ${ }^{1}$, Oleksandr VRUBLEVSKYI ${ }^{2}$ \\ ${ }^{1}$ Kharkiv National University of Automobile and Highways, Kharkov, \\ Jaroslawa Mudrego 25, 61-002 Charków, Ukraina, e-mail: dthkbd@ukr.net \\ ${ }^{2}$ University of Warmia and Mazury in Olsztyn, Faculty of Technical Sciences \\ Oczapowskiego 11A, 10-736 Olsztyn, Polska, e-mail: aleksander.wroblewski@uwm.edu.pl
}

Abstract

This article describes the details of the method designed to determine parameters of vehicle's internal combustion engine with compression ignition (CI) during road tests. The method requires simultaneous measurements for the crankshaft rotation frequency, fuel pressure in the injector, pressure in the combustion chamber, air pressure and temperature in the intake system. More, this method utilizes possibilities of the GPS navigation - all the received data is being synchronized with navigation data and saved to the database. Fuel consumption was calculated using the original method based on processing the pressure data from inside the cylinder alongside with the fuel injection parameters, previously received from the injection system and engine tests in the laboratory. Obtained characteristics allow to perform detailed analysis for the engine's single work cycle in the transient processes, which are the biggest part of engine's common work conditions. Measurements results received with help of the created experimental gear were used to determine CI engine parameters. Those parameters may help in simulation of the engine work inside the vehicle, and could be used in engine parameters optimization tasks.

Keywords: vehicle, diesel engine, measuring equipment, fuel consumption, cylinder pressure

\section{BADANIE SILNIKA O ZS W TEŚCIE DROGOWYM}

\section{Streszczenie}

W artykule przedstawiono szczegóły metody wyznaczenia parametrów oraz charakterystyk silnika o zapłonie samoczynnym (ZS) pojazdu podczas badań drogowych. Metoda ta polega na jednoczesnym pomiarze obrotów wału korbowego, ciśnienia paliwa we wtryskiwaczu, ciśnienia w komorze spalania, ciśnienia i temperatury powietrza w układzie dolotowym. Metoda łączy również system nawigacji GPS, z którego informacja jest synchronizowana $\mathrm{z}$ pozostałymi danymi z pomiarów i wpisana do wspólnej bazy danych. Zużycie paliwa zostało określone oryginalną metodą na podstawie przetwarzania wartości ciśnienia w cylindrze i wtrysku paliwa, wykorzystania rzeczywistych charakterystyk wtryskiwacza uzyskanych podczas badań laboratoryjnych układu paliwowego i silnika. Uzyskane charakterystyki wtrysku pozwalają szczegółowo analizować pojedynczy cykl pracy silnika w procesach przejściowych, z których prawie całkowicie składa się praca silnika samochodowego. Wyniki pomiarów za pomocą opracowanej aparatury badawczej zostały wykorzystane do wyznaczenia parametrów silnika ZS. Wyznaczone parametry pozwoliły odtworzyć działanie silnika podczas eksploatacji w pojeździe na hamowni silnikowej, dzięki czemu można zoptymalizować jego działanie jako jednostki napędowej w samochodzie.

Słowa kluczowe: pojazd, silnik o zapłonie samoczynnym, aparatura pomiarowa, zużycie paliwa, ciśnienie w cylindrze

\section{INTRODUCTION}

During the road tests it is possible to perform precise measurements of technical and ecological engine parameters, to compare the engine with another ones [1-6]. This experiment type could not be fully replaced with mathematical modelling or computer simulation [7-9]. During such experiments (apart from fuel consumption and movement characteristics) it is possible to determine required engine operation parameters and based on that, to choose optimal engine control parameters.

The method to determine working conditions of the vehicle's diesel engine was created during the road tests of the bus model RUTA-25d [10] (fig. 1) with engine 4DTNA1 [11] DA10 series Diesel Group (Ukraine).

Determination of actual engine parameters while it's working inside a vehicle is possible only using original testing gear, which allows to write movement parameters, fuel and air consumption, pressure and temperature. Those measurements received from the vehicle may be added to information about the vehicle's speed and the road's surface conditions.

Effective engine's work and diagnostics are possible only with electronic control systems applied [12, 13]. It could be said, that modern automobile is like «laboratory on the wheels». 
There are specific road tests often being applied, and during that tests it is possible to identify indicator and effective engine parameters, and fuel consumption $[4,6,8,14]$.

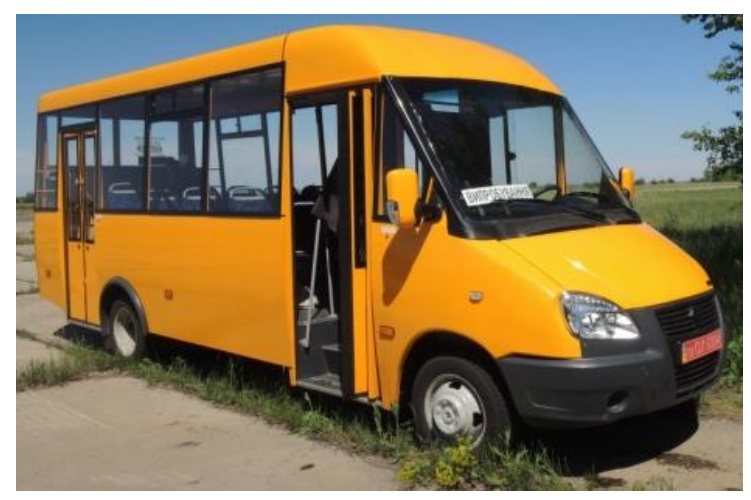

Fig. 1. Bus RUTA-25d

Literature sources contain description of the methods to identify fuel consumption based on energy consumption in the movement and $4 \mathrm{C}$ balance» [14]. The first method allows to check fuel consumption at constant load, but in the transient processes it does not offer good result quality. Fuel consumption check based on carbon balance (C-balance) demands to measure separate components amount into exhaust gases, which is quite problematic and expensive outside of the laboratory, on the road.

\section{AIM AND SCOPE OF THE WORK}

This work is aimed to prepare the set of the methods which will help to identify technical and exploitation engine parameters during a vehicle's road tests.

In order to achieve this target, it is vital to solve following problems:

- to develop the method to mount 4DTNA1 engine in the RUTA 25d engine compartment, which would also allow to use existing components of the Cummins ISF 2.8s systems [15] in the vehicle;

- to develop the mobile measurement system which allows to check technical and economical engine/vehicle parameters;

- to propose the method of fuel consumption measurements based on single fuel injection dose during the road tests;

- to analyse the vehicle's road tests results, obtained with help of mobile measurement system.

\section{RESEARCH FACILITY}

4DTNA1 engine was mounted instead of engine Cummins ISF $2.8 \mathrm{~s}$, with support of standard fuel system, cooling system, fuel system, intake and exhaust systems, all the control and operation systems (fig. 2).
After performed tests on the laboratory stand there were following actions applied to the engine in order to adapt it to operation with RUTA-25d:

- the Sachs joint and original cooler actuator pulley is used, as far as water pump and generator actuators;

- at the front side of the engine Borg Warner radiator fan with a viscous coupling is installed;

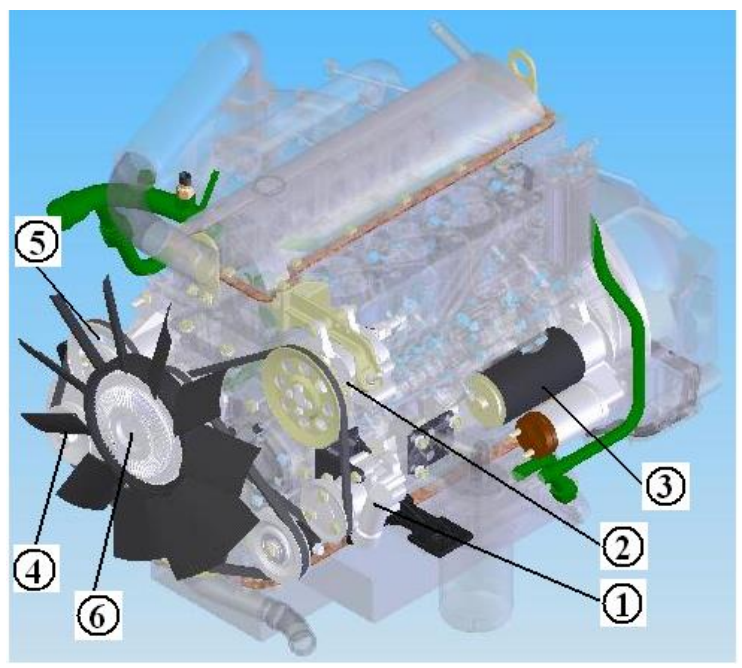

Fig. 2. Assemblies and subassemblies on the 4DTNA1 engine for installation on the RUTA 25d bus: 1 - power steering pump; 2 - brake system vacuum support pump; 3 - starter; 4 - alternator; 5 engine cooling system pump; 6 - fan

- the new turbocharger TKR 50.03.07 is installed instead of TKR 5.5S-4;

- the brake booster system vacuum pump is installed;

- the power steering pump is mounted on the bracket;

- the new hood is installed under the engine;

- the new mechanism for changing the fuel injection advance angle has been developed and installed;

- to power the electrical system, a 66 Ah battery is used, charged with an alternator with a power of $1.12 \mathrm{~kW}$ and an electric starter with a capacity of $2.1 \mathrm{~kW}$.

To provide 4DTNA1 assembling inside the bus engine compartment, following scope of work was performed:

- four $(2 \times 2)$ new holes in the vehicle's side elements, rubber damper is being used there, cooler is attached to the front mount of drive unit;

- 5 stage gearbox from GAZ is installed, the same as being used in many GAZelle automobiles equipped with ICE. Gear ratios shown in table 1 ;

- fuel system is upgraded in such way that new joints and adapters allow to plug in fuel feeding system from engine 4DTNA1; 
- cooling and heating systems were set up, alongside with intake and exhaust systems - to allow plugging in 4DTNA1 systems;

- automobile electrical system (fig. 3) was adapted to join the 4DTNA1 engine using signal converter, to allow data reading like crankshaft rotation speed, antifreeze temperature and oil pressure from standard indicators from the dashboard. Because of standard data bus RUTA-25 integration to the engine it is possible to control glow plugs using microcontroller from Cummins engine.

Table 1. Gear ratio

\begin{tabular}{|c|c|c|c|c|c|c|}
\hline Main gear & I & II & III & IV & V & R \\
\hline 4,556 & 4,050 & 2,340 & 1,395 & 1,000 & 0,849 & 3,510 \\
\hline
\end{tabular}

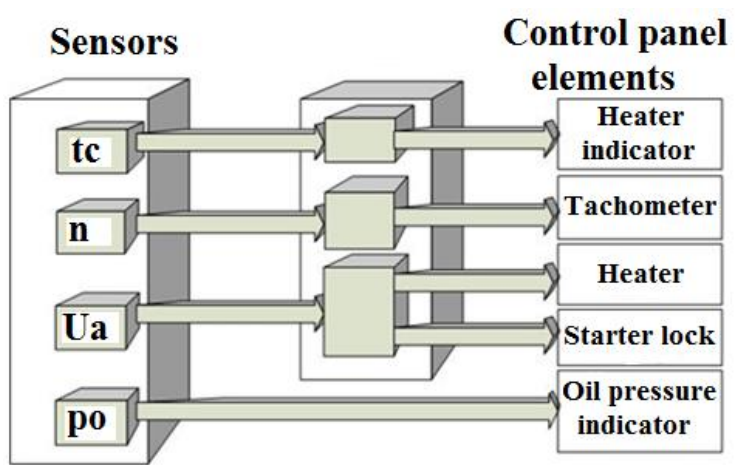

Fig. 3. Information channels building diagram in adapted electric system

\section{METHOD OF MEASURING ENGINE PARAMETERS}

GPS system was used to control the travelled distance with discretization frequency $1 \mathrm{sec}$, and appropriate measurements accuracy was obtained this way. During recorded data processing the data from GPS was synchronizes and compared with signal forms from data source sensors installed in the engine.

According to common methodology the engine additionally equipped with temperature and pressure sensors for intake air (fig. 4), installed in the intake collector. Measurements from these sensors allow to estimate intake system work and to evaluate momentary air flow to the cylinders.

Pressure sensor in the engine cylinder allows to make measurements for compression pressure and the info about mixture formation and fuel combustion. For the purpose of the in-cylinder pressure measurements special non-cooled AVL sensor is being used, which is installed using adapter for glow plug installation place (fig. 5).

Fuel injection parameters were controlled by signal from fuel pressure sensor installed in the injector (fig. 5). This signal makes possible to get actual fuel injection start time and injection pressure. Having pressure curve data and calibration results from fuel system laboratory tests, it is possible to calculate momentary fuel consumption values.

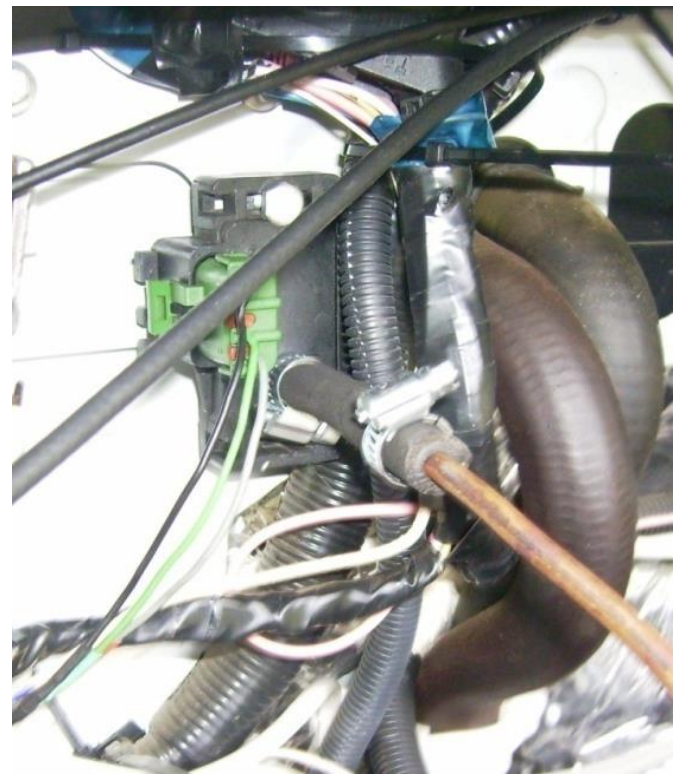

Fig. 4. The boost pressure sensor is mounted in the engine's intake system

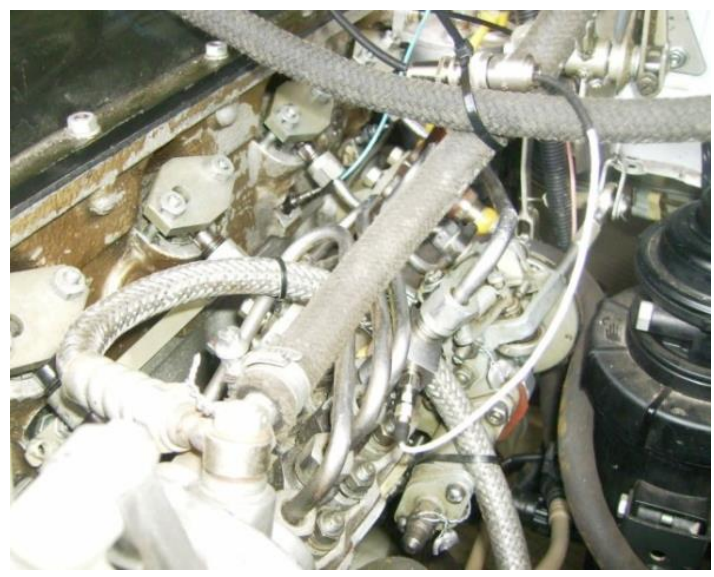

Fig. 5. A fragment of the engine head with mounted pressure sensors in the cylinders and fuel pressure sensors

Current crankshaft position was determined by signal generated in the processing module which supplies data to the tachometer.

All these mentioned signal measurement channels contained inside the measurement module, including the sensors, signal amplifiers and analogue-digital data converters.

According to created method, road tests include following:

- linear vehicle speed measurements and recording;

- fuel consumption evaluation;

- total and local fluctuations assessment;

- inner and outer noise level detection;

- exhaust gases structure measurements. 
Figure 6 shows measurement section diagram. In part B section A with length $2360 \mathrm{~m}$ max vehicle acceleration was measured, alongside with road tests for imitated countryside driving. Tests execution for the whole loop A-C-B-D gave possibility to perform the test phase targeted to exploitation fuel consumption measurements on the road sections with constant vehicle speed.

\section{MEASUREMENTS}

Results shown on fig. 6-8, tables 2, 3 are obtained using developed investigation methods and show that it is possible to achieve the main goal.

Max acceleration values recorded during the tests (tab. 2) show that for all speed ranges typical for city busses, diesel engine 4DTNA1 provides double or triple high acceleration compared to standard engine.

Table 2. Vehicle acceleration indicators RUTA 25d with 4DTNA1 engine

\begin{tabular}{|c|c|c|c|}
\hline Speed, $\mathrm{km} / \mathrm{h}$ & $0-20$ & $20-40$ & $40-60$ \\
\hline $\begin{array}{c}\text { Maximum acceleration of } \\
\text { the bus RUTA 25d, m/s }\end{array}$ & 1,3 & 1,15 & 1,1 \\
\hline
\end{tabular}

Comparison of the fuel consumption (tab. 3) on the RUTA busses equipped with different engines consuming different fuel types showed 4DTNA1 engine advantages.

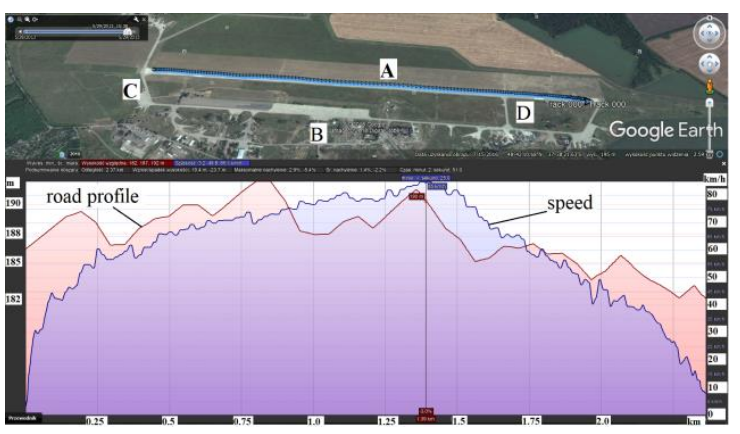

a)

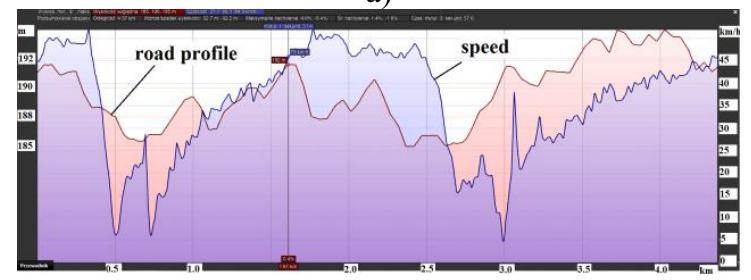

b)

Fig. 6. Test results registration in Google Earth: A - section with a length of $2360 \mathrm{~m}$; B - place for determining the noise level, vibration and smoke; A-C-B-D - ring length $4360 \mathrm{~m}$; a) -

changes in the linear velocity value and changes in the test track height in the acceleration measurement section; b) changes in the linear velocity and changes in the test track height along the whole test loop
Figure 7 shows the example of values recorded during max acceleration tests. Oscillograms 2-4 (fig.7) determine parameters of working processes in the engine. Curve 5 which shows crankshaft rotation frequency changes has been received during test results processing.

Table 3. Comparison of the value of fuel output

\begin{tabular}{|c|c|c|c|c|c|}
\hline \multirow{3}{*}{$\begin{array}{c}\text { Road } \\
\text { surface, type } \\
\text { of measuring } \\
\text { cycle }\end{array}$} & \multirow{3}{*}{$\begin{array}{c}\text { Average } \\
\text { speed of } \\
\text { movement, } \\
\mathrm{km} / \mathrm{h}\end{array}$} & \multicolumn{4}{|c|}{ Fuel consumption $1 / 100 \mathrm{~km}$} \\
\hline & & \multirow{2}{*}{$\begin{array}{c}\text { 4DTNA1 } \\
\text { ZS }\end{array}$} & \multirow{2}{*}{$\begin{array}{c}\text { Cummins } \\
\text { ISF 2.8s } \\
\mathrm{ZS}\end{array}$} & \multicolumn{2}{|c|}{ UMZ-4216 } \\
\hline & & & & ZI & LPG \\
\hline \multirow{2}{*}{$\begin{array}{l}\text { Concrete. } \\
\text { Extra-urban } \\
\text { cycle. } \\
\text { Airport }\end{array}$} & 62,5 & 10,4 & - & - & - \\
\hline & 78,3 & 11,6 & - & - & - \\
\hline $\begin{array}{l}\text { Asphalt. } \\
\text { Mixed cycle }\end{array}$ & 50,4 & 12,2 & - & - & - \\
\hline $\begin{array}{l}\text { Asphalt. City } \\
\text { cycle }\end{array}$ & 23,6 & 12,1 & 12,5 & 18,5 & 24,5 \\
\hline
\end{tabular}

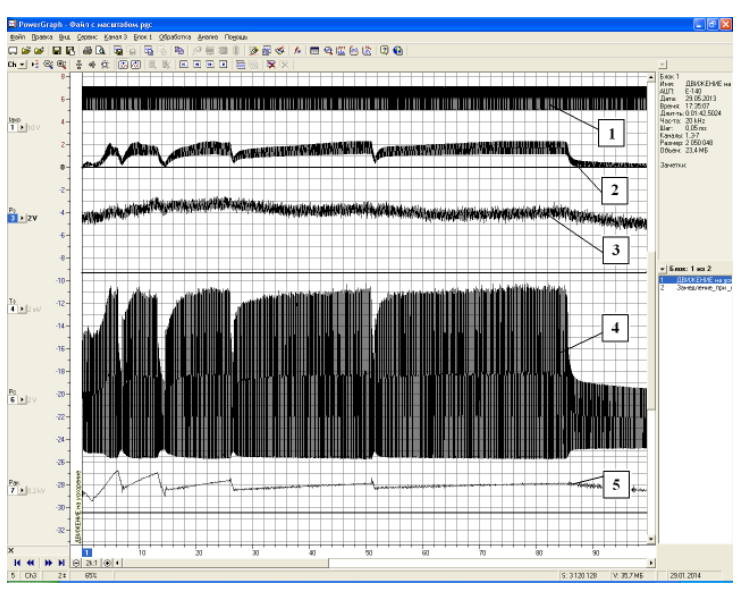

Fig. 7. Data collection window (bus moves with maximum acceleration): 1 - crankshaft position signal; 2 - boost pressure; 3 - air temperature in the intake manifold; 4 - cylinder pressure; 5 - change of engine crankshaft speed

In the same way, fuel consumption changes shown on the fig. 9 are the consequences of pressure data curves (pressure before the injectors) processing, which allows to evaluate pressure drop $\Delta P=P_{f}-P_{c}$ during injection time period

$$
q=\mu f \cdot \sqrt{2 / \rho \cdot \Delta P},
$$

where $q$ - fuel dose, $\mu f$ - effective sprayer section in the injector, $\rho$ - fuel density, $\Delta P$ - pressure drop, $P_{f}$ pressure before the injector, $P_{c}$ - pressure in the combustion chamber.

The characteristics of the change in the effective sprayer cross section for the injector of the tested diesel engine were obtained during preliminary laboratory tests [3].

The results of applying corresponding methods for evaluating fuel consumption in the vehicle acceleration is given on the figure 9 . 


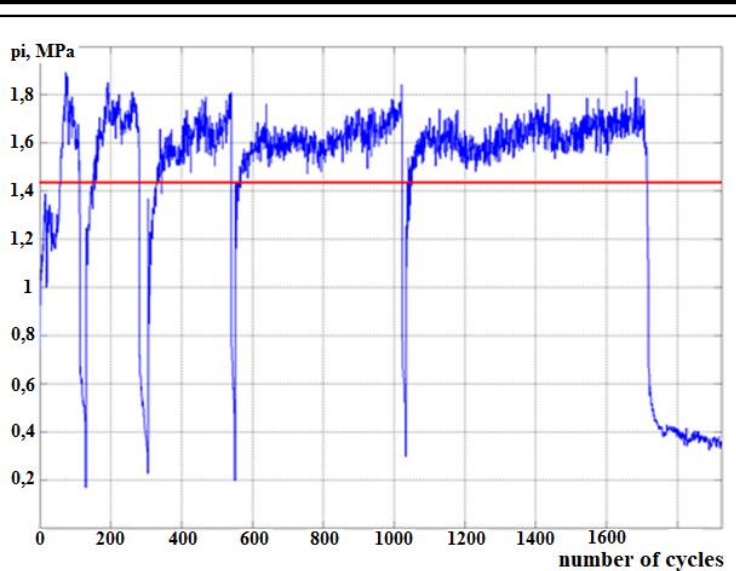

a)

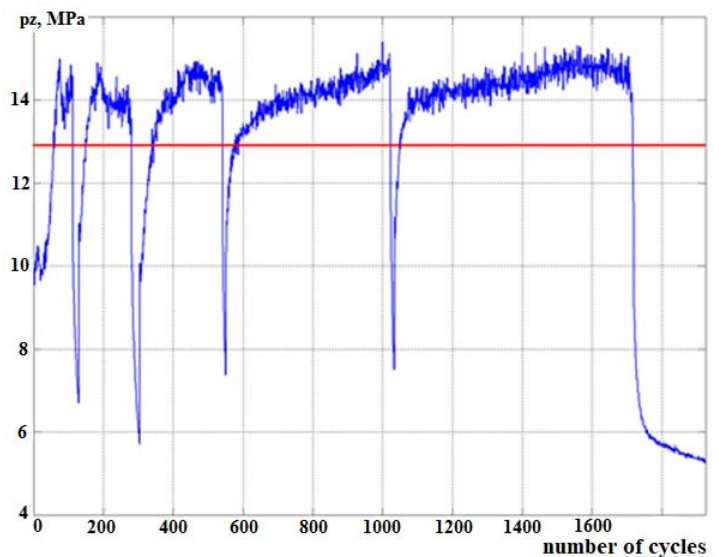

b)

Fig. 8. Results of the development of the pressure change in the cylinder: a) average indicated pressure, $b$ ) maximum pressure during combustion

Fuel output data (fig. 9) allows to conduct full single work cycle analysis during transient processes, which is almost totally means engine work in the city traffic.

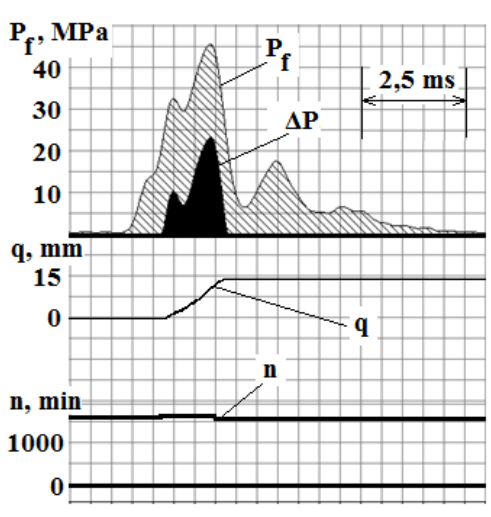

Fig. 9. The results of determining the fuel output $\left(\mathrm{P}_{\mathrm{f}}\right.$ - fuel pressure, $\mathrm{n}$ - crankshaft rotation, $\mathrm{q}$ fuel expenditure)

Measurements results received with help of the created experimental gear were used to determine $\mathrm{CI}$ engine parameters. And also in the identification of the simulation model (Fig. 10, 11), created in the AmeSIM program and used to determine the characteristics of the object in various operating conditions, optimize the design and adjusting parameters of the engine, and also test the methods for diagnosing diesel and other vehicle components.

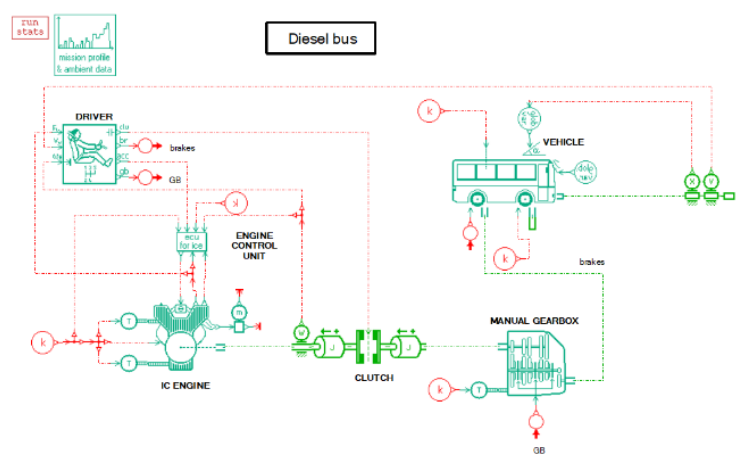

Fig. 10. Bus simulation model

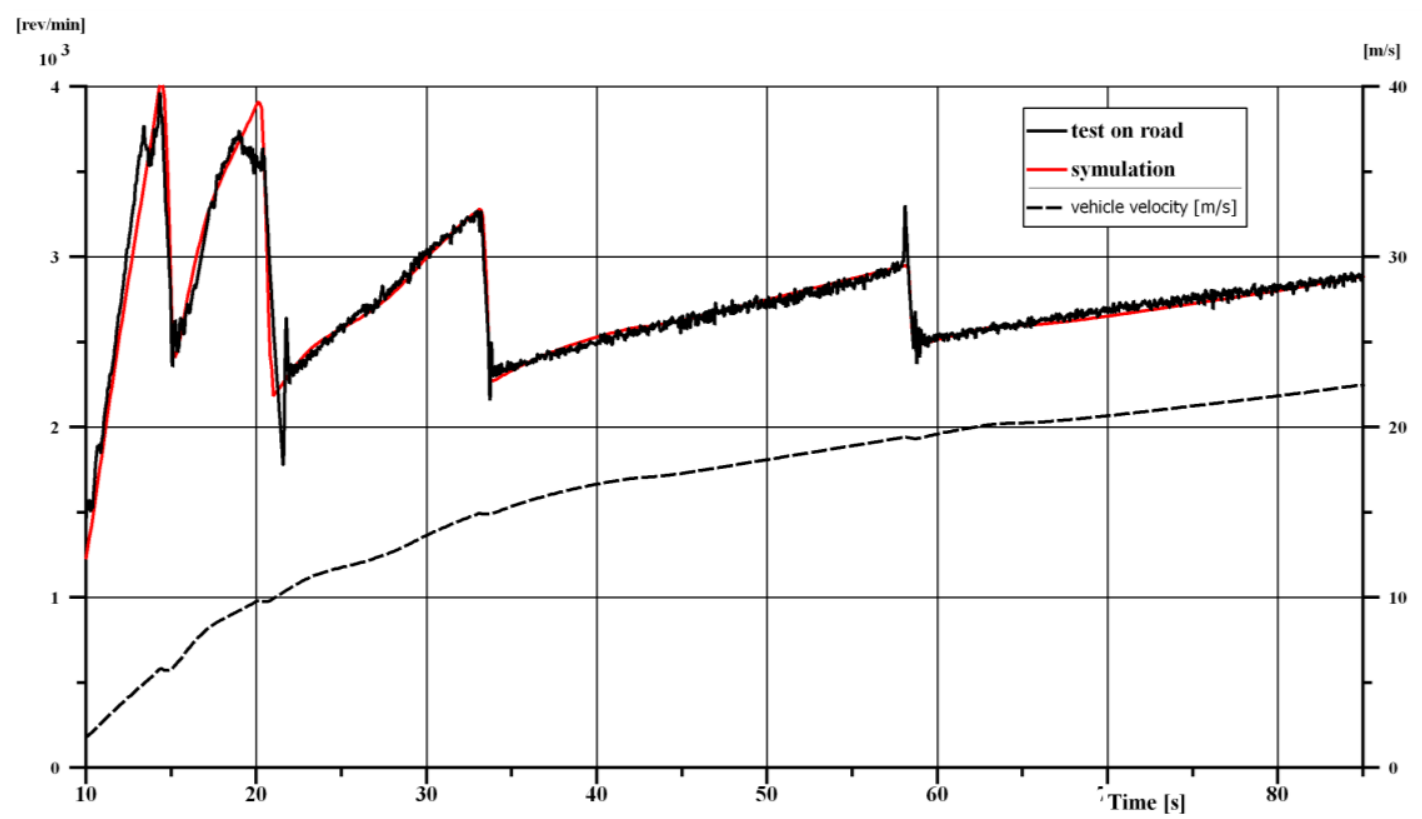

Fig. 11. Model validation results 


\section{CONCLUSIONS}

The engine test object 4DTNA1 installed in the RUTA25d bus compartment instead of the Cummins ISF 2.8s diesel fuel elements fixing the regular bus fuel system, engine cooling and cab heating system, air filter and exhaust system, power steering and vacuum brake system amplifier.

Proposed electric circuit mixed by a combination established by the 4DTNA1 engine speed sensor, coolant temperature and oil pressure into the instrument panel through the block fitting process.

A mobile measuring system was developed to study the technical and economic performance of the engine and vehicle. The complex allows the measurement of pressure in the engine cylinder, fuel injection pressure, boost air parameters. The complex also includes a GPS navigation system, from which the information was synchronized with the data of other measurements and entered into the common database ago, there is the possibility of remote online data collection.

Fuel consumption was determined by the original method described on the basis of the processing of the characteristics of cylinder pressure change and fuel injection. The accuracy of the results was ensured by using the basic characteristics obtained during laboratory tests of the fuel system and the engine. The obtained characteristics of the injection allow to analyse in detail the single cycle of the engine work in the transition processes, which almost entirely consists of the work of the car engine.

The measurement results using the created complex were used to determine the parameters of the CI engine. The parameters determined allows to reproduce the operation of the engine during operation in the vehicle on the engine dynamometer, thanks to which it can be optimized as a drive unit in the car.

\section{REFERENCES}

1. Kwon S, Kang M, Seo Y, Par S. Effects of test conditions on fuel economy of gasoline-powered vehicle. IJAT, 2018; 19(2):253-261. https://doi.org/10.1007/s12239-018-0024-1

2. Celiński I. Mobile diagnostics of vehicles as a means to examine and define speed limits in a road. Diagnostyka, 2017; 18(1):67-72.

3. Jayaratne ER, Meyer NK, Ristovski ZD, Morawska L. Volatile properties of particles emitted by compressed natural gas and diesel buses during steady-state and transient driving modes. Environmental Science and Technology, 2012; 46(1): 196-203. https://doi.org/10.1021/es2026856

4. Tong HY, Hung WT, Cheung CS. On-road motor vehicle emissions and fuel consumption in urban driving conditions. Journal of the Air \& Waste Management Association, 2000;50(4):543-554, https://doi.org/10.1080/10473289.2000.10464041

5. Kwak JH, Kim HS, Lee JH, Lee SH. On-road chasing measurement of exhaust particle emissions from
Diesel, CNG, LPG, and DME-fueled vehicles using a mobile emission laboratory. IJAT, 2014;15(4): 543551. https://doi.org/10.1007/s12239-014-0057-z

6. Wu Y, Zhang S, Hao J, Liu H. Real-world emissions and fuel consumption of diesel buses and trucks in Macao: from on-road measurement. Atmospheric Environment. 2015;120:393-403.

https://doi.org/10.1016/j.atmosenv.2015.09.015

7. Esser A, Zeller M, Foulard S, Rinderknecht S. Stochastic synthesis of representative and multidimensional driving cycles. SAE paper 201801-0095.

8. Bifulco GN, Galante F, Pariota L, Spena MR. A linear model for the estimation of fuel consumption and the impact evaluation of advanced driving assistance systems. Sustainability 2015; 7:1432614343. https://doi.org/10.3390/su71014326

9. Daebong J, Junghwan B, Seungmok C, Hoimyung C, Kyoungdoug M. Optimization algorithm for diesel engine operating parameters based on a vehicle driving test cycle. Journal of Mechanical Science and Technology. 2013;27(7):2171-2179. https://doi.org/10.1007/s12206-013-0536-6

10. Krynik LV. Design school of bus construction (for the 50th anniversary of the Ukrautobusprom Institute). Lviv: National Academy of Ground Forces, 2015.

11. Grytsyuk OV. The chief designer's responsibility for the destiny of development. Saarbrucken: Lambert Academic Publishing, 2017.

12. Wohlthan M, Pirker G, Wimmer A. Modular fault diagnosis system for engine test bed measurements. SAE Int. J. Commer. Veh. 2017;10(1):159-169. https://doi.org/10.4271/2017-01-0386

13. Lambert M, Tesfa B. Robust application of CBE and OBE for engine testing system diagnosis. SAE Technical Paper 2016-01-0987, 2016. https://doi.org/10.4271/2016-01-0987

14. Ubysz A. Measurement technology and calculation of fuel consumption in vehicles. Gliwice: Wyd. Politechniki Sląskiej, 2012.

15. https://cumminsengines.com/repower.aspx

Received 2018-02-06

Accepted 2018-04-23

Available online 2018-04-26

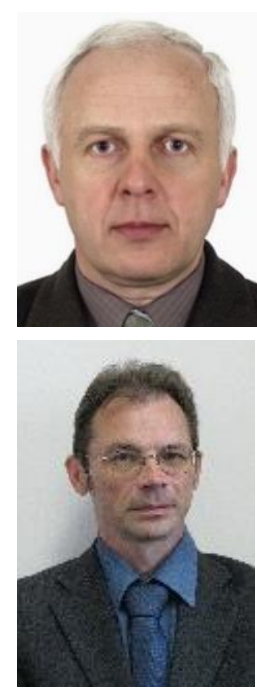

Oleksandr GRYTSYUK

DSc., DEng. - professor in the Faculty of Automotive, the Kharkiv National University of Automobile and Highways, Kharkov.

Oleksandr VRUBLEVSKYI,

DSc., DEng. - adjunct in the Faculty of Technical Sciences, the University of Warmia and Mazury in Olsztyn 